\title{
Influence of wet vs. dry by-product ingredients and addition of branched-chain volatile fatty acids and valerate to dairy diets. 1 . Feed intake, milk production and milk composition
}

\section{H. de Visser and S. Tamminga}

Institute for Livestock Feeding and Nutrition Research (IVVO), P.O. Box 160, 8200 AD Lelystad, Netherlands.

Received 8 October 1986; accepted 9 March 1987

Key words: cow, intake, milk production, by-products, isoacids

\begin{abstract}
A feeding trial was carried out with 56 dairy cows in the first 18 weeks of lactation. Rations consisted of grass silage and maize silage as roughage components, and concentrates based entirely on by-product ingredients. Two groups were formed in which the by-products were fed in a dehydrated (DRY) or in an ensiled (WET) form.

Half of each group received no additive (MINUS) or an additive (PLUS) containing calcium salts of isoacids (iso-butyrate, 2-methyl butyrate, 3-methyl butyrate) and valerate.

No significant effect of the use of the additive was found on feed intake, milk production and milk composition.

Dutch rations based on grass silage and several by-product ingredients with comparatively high protein levels may have sufficient sources of branched-chain carbon skeletons for rumen bacterial growth.

Feed, energy and protein intake, milk protein content and milk protein production were significantly lower after feeding the WET diet as compared to the DRY diet.
\end{abstract}

\section{Introduction}

Use of by-products in dairy cattle feeding is common in the Netherlands. In the past 10 years more than $90 \%$ of concentrate ingredients for dairy cattle were by-products.

In the last few years a tendency has developed to use more ensiled by-products because of high costs of dehydration due to increasing prices of fossil energy. Con- 
centrates are partially substituted with wet by-products. Increasing the moisture content of the diet could decrease voluntary dry matter intake (Lahr et al., 1983). The nature of the energy available in the feed after ensiling or dehydration differs. During ensiling easily fermentable carbohydrates are rapidly used by micro-organisms for maintenance and growth. As a result, less energy is left for rumen microorganisms, which could decrease total microbial protein synthesized. This may lead to a reduced flow of amino acids to the lower gastrointestinal tract (Miller, 1982; Van Soest, 1982), which may result in lower availability of amino acids for synthesis of milk protein.

Experimental results from the USA (Papas et al., 1984; Pierce-Sandner et al., 1985 ) indicate a positive influence of dietary addition of branched-chain volatile fatty acids (iso-butyrate, 2-methyl butyrate, 3-methyl butyrate) as well as the straight-chain volatile fatty acid valerate (isoacids) on the production of milk and efficiency by which it is produced. In these studies typical American rations were used, which were largely based on maize products and contained substantial amounts of non-protein nitrogen.

To investigate the usefulness of isoacids under Dutch feeding conditions a trial was carried out in which isoacids and valerate were added to a ration containing wilted grass silage and maize silage as the roughage components. In addition concentrates based on by-product ingredients were fed either in a dehydrated form or wet ensiled.

This study was completed with a metabolism study with four dairy cows fed the same diets (Robinson et al., 1987a, 1987b).

\section{Materials and methods}

A feeding trial was completed with 56 dairy cows which were either purebred Dutch Friesian or crossbred Dutch Friesian $\times$ Holstein Friesian black and whites. All animals were in second or higher lactation. The trial started on the day of parturition and was continued for 18 weeks.

Prior to the start of the trial animals were allocated over four equal groups based on age and production in previous lactations (Table 1). Animals were fed complete mixed diets twice daily by using a feeding mixing wagon. Of the total daily ration $40 \%$ was offered at $05 \mathrm{~h} 00$ and $60 \%$ at $15 \mathrm{~h} 00$. Feeding after parturition started with $15 \mathrm{~kg}$ dry matter. Ad libitum intake was achieved and maintained by adjusting every second or third day the daily amount of feed offered. Adjustments were governed by the aim to have refusals of less than $1 \mathrm{~kg}$ of material as fed, but were applied in portions of $1 \mathrm{~kg}$ of dry matter of the totally mixed diet. On a dry matter basis the diets consisted of $40 \%$ roughage (wilted grass silage and maize silage in a 50:50 ratio) and $60 \%$ concentrates. Part (60\% on a dry matter basis) of the concentrate ingredients (beet pulp, maize gluten feed and brewers' grains) were fed either ensiled (WET) or dehydrated (DRY). Wet and dry by-product ingredients were from different batches. The energy/protein ratio of the diet was calculated with the Dutch Net Energy Lactation system (van Es, 1978) and digestible crude protein (DCP) as advised in 1983 by the Central Bureau of Livestock Feeding in the Ne- 
Table 1. Average milk production, milk composition, and age of the cows in previous lactations.

\begin{tabular}{lcccc} 
& DRY MINUS & DRY PLUS & WET MINUS & WET PLUS \\
Milk (kg/year) & 5269 & 5243 & 5308 & 5229 \\
Fat (\%/year) & 4.29 & 4.29 & 4.28 & 4.30 \\
Protein (\%/year) & 3.34 & 3.35 & 3.34 & 3.34 \\
Age (months) & 53 & 53 & 54 & 52 \\
\hline
\end{tabular}

Table 2. Chemical composition, energy and protein values of roughages and ensiled by-products used in the experiment.

\begin{tabular}{|c|c|c|c|c|c|}
\hline & $\begin{array}{l}\text { Grass } \\
\text { silage } \\
\text { (wilted) }\end{array}$ & $\begin{array}{l}\text { Maize } \\
\text { silage }\end{array}$ & $\begin{array}{l}\text { Beet } \\
\text { pulp } \\
\text { (pressed) }\end{array}$ & $\begin{array}{l}\text { Maize } \\
\text { gluten }\end{array}$ & $\begin{array}{l}\text { Brewers' } \\
\text { grains }\end{array}$ \\
\hline \multicolumn{6}{|l|}{ Chemical composition } \\
\hline Dry matter $(\mathrm{g} / \mathrm{kg})$ & 537 & 291 & 191 & 438 & 257 \\
\hline $\operatorname{Ash}(g / k g D M)$ & 119 & 71 & 132 & 50 & 55 \\
\hline Crude protein (g/kg DM) & 213 & 94 & 105 & 209 & 250 \\
\hline Crude fibre (g/kg DM) & 257 & 223 & 206 & 86 & 172 \\
\hline Crude fat (g/kg DM) & n.a. & n.a. & 7 & 28 & 99 \\
\hline \multicolumn{6}{|l|}{ Neutral detergent fibre } \\
\hline$(\mathrm{g} / \mathrm{kg} \mathrm{DM})$ & 493 & 451 & 498 & 377 & 628 \\
\hline Starch $(\mathrm{g} / \mathrm{kg} \mathrm{DM})$ & - & n.a. & - & 219 & 16 \\
\hline \multicolumn{6}{|l|}{ Energy and protein values } \\
\hline$(\mathrm{MJ} / \mathrm{kg} \mathrm{DM})$ & 5.93 & 5.91 & 6.62 & 7.22 & 5.03 \\
\hline \multicolumn{6}{|l|}{ Digestible crude protein } \\
\hline$(\mathrm{g} / \mathrm{kg} \mathrm{DM})$ & 159 & 54 & 65 & 154 & 186 \\
\hline Acetic acid (g/kg DM) & 2.0 & 2.0 & 2.0 & 1.22 & 5.0 \\
\hline Butyric acid (g/kg DM) & - & - & - & - & 1.0 \\
\hline Lactic acid (g/kg DM) & 8.6 & 15.3 & 7.0 & 27.8 & 1.0 \\
\hline Alcohol (g/kg DM) & 1.0 & 1.1 & 1.8 & 0.6 & 0.5 \\
\hline
\end{tabular}

n.a. = not analysed.

therlands. On a dry matter basis an equal amount of each by-product ingredient was fed in each treatment (WET or DRY). The chemical composition of the roughages and ensiled by-products is shown in Table 2. The ingredient profile and chemical composition of the concentrates is shown in Table 3. Organic matter digestibility of the used by-products (beet pulp, maize gluten feed and brewers' grains) was estimated by the in vitro technique of Tilley \& Terry (1963) as adapted at IVVO by van der Meer (unpublished). The results were corrected to in vivo values by using standard samples of known in vivo digestibility. Both the ensiled and the dehydrated form of maize gluten feed and brewer's grains were tested for in vivo digestibility with wethers. The wethers were fed at or close to maintenance with a basal diet of ca. $250 \mathrm{~g} \mathrm{DM}$ as long meadow hay and ca. $750 \mathrm{~g} \mathrm{DM}$ from the by-product to be in- 
Table 3. Ingredients and chemical composition of the concentrates used in the experiment.

\begin{tabular}{|c|c|c|c|c|}
\hline & DRY MINUS & DRY PLUS & WET MINUS & WET PLUS \\
\hline \multicolumn{5}{|l|}{ Ingredient composition (\%) } \\
\hline Beet pulp (dehydrated) & 30.0 & 30.0 & - & - \\
\hline Maize gluten feed (dehydrated) & 20.0 & 20.0 & - & - \\
\hline Brewers' grains (dehydrated) & 10.0 & 10.0 & - & - \\
\hline Soya bean meal & 10.0 & 10.0 & 25.0 & 25.0 \\
\hline Coconut expeller & 7.5 & 7.5 & 18.8 & 18.8 \\
\hline Palm kernel expeller & 7.5 & 7.5 & 18.8 & 18.8 \\
\hline Cane molasses & 3.0 & 3.0 & 7.5 & 7.5 \\
\hline Animal fat (tallow) & 1.0 & 1.0 & 2.5 & 2.5 \\
\hline Soya bean hulls & 8.2 & 8.2 & 20.5 & 20.5 \\
\hline Minerals and vitamins & 2.8 & 2.8 & 6.9 & 6.9 \\
\hline Isoacids (ISOPLUS ${ }^{\mathrm{TM}}$ ) & - & 0.7 & - & 2.1 \\
\hline \multicolumn{5}{|l|}{ Chemical composition } \\
\hline Dry matter $(\mathrm{g} / \mathrm{kg})$ & 894 & 894 & 894 & 891 \\
\hline $\operatorname{Ash}(g / k g D M)$ & 100 & 102 & 124 & 128 \\
\hline Crude protein (g/kg DM) & 194 & 194 & 216 & 210 \\
\hline Crude fibre (g/kg DM) & 143 & 143 & 169 & 163 \\
\hline Crude fat (g/kg DM) & 45 & 44 & 74 & 69 \\
\hline \multicolumn{5}{|l|}{ Neutral detergent fibre } \\
\hline$(\mathrm{g} / \mathrm{kg} \mathrm{DM})$ & 389 & 393 & 427 & 406 \\
\hline Sugars $(g / k g ~ D M)$ & 107 & 111 & 94 & 96 \\
\hline Starch $(\mathrm{g} / \mathrm{kg} \mathrm{DM})$ & 54 & 53 & 12 & 18 \\
\hline \multicolumn{5}{|l|}{ Net energy lactation } \\
\hline \multicolumn{5}{|l|}{ Digestible crude protein } \\
\hline$(\mathrm{g} / \mathrm{kg} \mathrm{DM})$ & 151 & 151 & 179 & 179 \\
\hline \multicolumn{5}{|l|}{ Digestibility in vitro } \\
\hline (organic matter) & 83.4 & 83.6 & 81.0 & 81.0 \\
\hline
\end{tabular}

vestigated. Apparent digestibility was calculated by difference assuming that digestibility of hay and by-product ingredients were additional.

Half the number of animals receiving the WET or DRY diet received a supplement with approximately $80 \mathrm{~g}$ calcium salts of the isoacids iso-butyrate, 2-methyl butyrate, 3-methyl butyrate and the straight-chain volatile fatty acid valerate (ISOPLUS $^{\mathrm{TM}}$ ) (PLUS), the other half received no supplement (MINUS).

Milk production was recorded and sampled during two consecutive days a week. Samples were taken for individual milkings and analysed for fat and protein content. Live weight of the animals was measured once a week. The results of the trial were statistically analysed as a $2 \times 2$ factorial design. The results were also tested for possible interactions between the two factors involved (type of diet versus additive). For analysis the statistical programme Genstat was used (Alvey et al., 1982). 


\section{Results and discussion}

During the trial one animal (1170) of group DRY MINUS had to be removed from the trial because of sepsis. From week fourteen onwards the results of this animal were lost.

Results of in vitro digestibility of beet pulp, maize gluten feed and brewers' grains (ensiled or dehydrated) (Table 4) and results of in vivo digestibility of maize gluten feed and brewers' grains (ensiled or dehydrated) are given in Table 5. In vitro digestibility of beet pulp is high, which is in agreement with previous observations at IVVO (Steg \& Haaksma, unpublished). No difference is found between ensiled or dehydrated beet pulp. Digestibility in vitro of organic matter of the maize gluten feed (ensiled or dehydrated) agrees with results of previous trials. However, in vivo digestibility of the ensiled maize gluten feed is lower than expected. Especially the dehydrated maize gluten feed is extremely low in digestibility in vivo. Chemical composition cannot explain these differences. In previous trials Steg (unpublished) found good relationships between in vivo and in vitro digestibility of the organic matter for dehydrated maize gluten feed. Calculation of energy value of the maize gluten feed of the feeding trial is based on in vitro digestibility.

The digestibility of the ensiled brewers' grains is lower than expected. The ranking of the results in vivo and in vitro are in agreement with each other. The ensiled brewers' grains must have been of poor quality, not only when compared with the dehydrated form fed in this experiment, but also in comparison with other batches of which organic matter digestibility has been studied in vitro and in vivo.

Table 4. Digestibility $(\%)$ in vitro of organic matter in beet pulp, maize gluten feed, and brewers' grains.

\begin{tabular}{lll}
\hline & \multicolumn{2}{l}{ Digestibility in vitro } \\
\cline { 2 - 3 } & dehydrated & ensiled \\
Beet pulp & 86.8 & 86.2 \\
Maize gluten feed & 85.7 & 87.2 \\
Brewers' grains & 67.8 & 58.2 \\
\hline
\end{tabular}

Table 5. Digestibility (\%) in vivo of maize gluten feed and brewers' grains.

\begin{tabular}{llllll}
\hline Digestibility & \multicolumn{2}{l}{ Maize gluten feed } & & \multicolumn{2}{l}{ Brewers' grains } \\
\cline { 2 - 3 } \cline { 5 - 6 } \cline { 5 - 6 } dehydrated & ensiled & & & \\
Dry matter & 71.4 & 78.7 & & 57.3 & 44.7 \\
Organic matter & 75.0 & 81.9 & 60.9 & 48.9 \\
Crude protein & 65.5 & 71.5 & & 68.1 & 74.3 \\
Crude fat & 76.4 & 72.1 & & 86.7 & 89.9 \\
Crude fibre & 57.2 & 76.5 & & 28.4 & 15.5 \\
Nitrogen free extract & 81.3 & 87.0 & & 62.7 & 37.2 \\
\hline
\end{tabular}


Interaction between type of diet (WET versus DRY) and addition of isoacids (MINUS or PLUS) was first tested for significance. No significant interactions were found. Thus results were analysed for main effects according to the $2 \times 2$ factorial design.

\section{Effect of MINUS versus PLUS treatment}

The results of the addition of isoacids are given in Table 6. Lack of significant differences in milk production parameters between MINUS and PLUS groups are not in agreement with those of Papas et al. (1984) and Pierce-Sandner et al. (1985) who observed a significant difference in milk production for groups fed isoacids. However in their study feed intake was significantly higher for isoacids groups in the first weeks post partum, which might explain higher milk production due to the higher energy intakes. In the later part of lactation some of their groups were fed according to milk yield, which might explain continuation of the difference in milk yields.

Probably the differences between our study and those of Papas et al. (1984) and Pierce-Sandner et al. (1985) are a consequence of the difference in composition of diets. In our trial a higher content of crude protein was fed (18\% versus $14 \%$ in the

Table 6. Dry matter intake, milk production, milk composition and energy and protein intake and requirements.

\begin{tabular}{|c|c|c|c|c|c|c|}
\hline & MINUS & PLUS & DRY & WET & SEM & Sign. \\
\hline Roughage intake (kg DM) & 8.5 & 8.2 & 8.4 & 8.2 & 0.14 & NS \\
\hline $\begin{array}{l}\text { Concentrate and by-product } \\
\text { intake (kg DM) }\end{array}$ & 12.1 & 11.9 & $12.6^{\mathrm{a}}$ & $11.4^{\mathrm{b}}$ & 0.17 & $P<0.01$ \\
\hline Total dry matter intake (kg DM) & 20.6 & 20.1 & $21.1^{\mathrm{a}}$ & $19.6^{\mathrm{b}}$ & 0.26 & $P<0.01$ \\
\hline Net energy lactation intake (MJ) & 136 & 133 & $143^{\mathrm{a}}$ & $128^{\mathrm{b}}$ & 1.68 & $P<0.01$ \\
\hline $\begin{array}{l}\text { Net energy lactation } \\
\text { requirement (MJ) }\end{array}$ & 141 & 138 & 142 & 138 & 2.33 & NS \\
\hline Net energy supply (\%) & 98 & 97 & $102^{\mathrm{a}}$ & $93^{\mathrm{b}}$ & 1.24 & $P<0.01$ \\
\hline $\begin{array}{l}\text { Digestible crude protein } \\
\text { intake }(\mathrm{g})\end{array}$ & 2716 & 2650 & $2827^{\mathrm{a}}$ & $2539^{\mathrm{b}}$ & 33.4 & $P<0.01$ \\
\hline $\begin{array}{l}\text { Digestible crude protein } \\
\text { requirement }(\mathrm{g})\end{array}$ & 2483 & 2423 & 2484 & 2422 & 42.5 & NS \\
\hline $\begin{array}{l}\text { Digestible crude protein } \\
\text { supply }(\%)\end{array}$ & 109 & 109 & $114^{\mathrm{a}}$ & $105^{\mathrm{b}}$ & 1.14 & $P<0.01$ \\
\hline Milk (kg) & 31.8 & 30.8 & 31.7 & 30.9 & 0.64 & NS \\
\hline Milk fat $(\%)$ & 4.29 & 4.29 & 4.31 & 4.29 & 0.05 & NS \\
\hline Milk protein $(\%)$ & 3.17 & 3.17 & $3.21^{\mathrm{a}}$ & $3.13^{\mathrm{b}}$ & 0.03 & $P<0.05$ \\
\hline Milk fat $(\mathrm{g})$ & 1362 & 1323 & 1362 & 1323 & 29.1 & NS \\
\hline Milk protein $(\mathrm{g})$ & 1006 & 976 & $1015^{\mathrm{a}}$ & $967^{b}$ & 16.6 & $P<0.05$ \\
\hline Fat-corrected milk (kg) & 33.2 & 32.2 & 33.1 & 32.2 & 0.66 & NS \\
\hline Live weight $(\mathrm{kg})$ & 611 & 611 & 618 & 604 & 11.7 & NS \\
\hline
\end{tabular}

$\mathrm{SEM}=$ standard error of mean.

NS = not significant.

Figures with a different superscript are significant $(P<0.05)$. 
DM), because protein feeding standards in the Netherlands are higher than in the USA. In most of the diets applied by Papas et al. (1984) and Pierce-Sandner et al. (1985) a large proportion of dietary crude protein was maize protein and often a substantial part of the dietary crude protein was fed as non-protein nitrogen (urea). In our trial five products relatively rich in protein were used (soya bean meal, maize gluten feed, palm kernel expeller, coconut expeller, brewers' grains).

Degradation of these protein sources may have led to an adequate supply of isoacids in the rumen. Using one major protein source as was the case in the trials of Papas et al. (1984) and Pierce-Sandner et al. (1985) may supply suboptimal amounts of isoacids for rumen fermentation due to an inadequate amino acid profile. Degradation of non-protein nitrogen (urea) does not contribute to the pool of isoacids in the rumen. Robinson et al. (1987a) fed the same diets to rumen-cannulated dairy cows and their results indeed suggested an adequate supply of isoacids in the rumen after feeding diets without supplement of isoacids. Nevertheless, these authors observed increased rumen concentrations of isoacids when ISOPLUS ${ }^{\mathrm{TM}}$ was added to the ration. It is therefore likely that the amount of isoacids produced on the MINUS diets was sufficient to optimize rumen bacterial growth. Thus supplemental isoacids from the ISOPLUS ${ }^{\mathrm{TM}}$ would not increase bacterial growth and efficiency of bacterial growth.

Use of one major protein source in a concentrate for dairy cows is not common in the Netherlands, nor is it likely to be in the near future. Non-protein nitrogen is very seldom used in dairy rations. At present supplemental isoacids do not seem promising for Dutch dairy rations based on grass and by-product ingredients with crude protein levels between 17 and $20 \%$ of the dry matter. There is however an increasing interest in maize silage as a major component of dairy rations and research on the effect of a supplement of isoacids with diets largely based on maize silage seems of interest.

\section{Effect of DRY and WET treatment}

The results of the type of diet (WET or DRY) are shown in Table 6. Dry matter content in different batches of the ensiled by-products, especially the pressed beet pulp, within one silo varied more than expected. This has led to overestimation of the dry matter content, resulting in a lower amount of dry matter from pressed beet pulp in total dry matter of the WET diet compared with the DRY diet.

The amount of roughage eaten by the cows did not differ significantly between DRY and WET groups. The concentrate and by-product intake was however significantly lower for the WET group.

Differences were not similar during the entire experiment. Especially in the early weeks of lactation the difference was more pronounced.

Dry matter intake of the DRY ration declined in the second part of the experiment to a greater extent than cows fed WET diets. This might be due to the increased temperature in the stall. Storage of the WET diet in a refrigerator to prevent heating may have slowed the drop in feed intake for WET diets. However, total dry matter intake over the entire experimental period was significantly lower for the WET diet. Lower total dry matter intake of the WET diet may partly be a con- 
sequence of the lower digestibility of the ensiled brewers' grains (Table 4). Higher moisture content of total ration may have influenced total dry matter intake as well. Lahr et al. (1983) found highest dry matter intakes when dry matter content of the diet was approximately $60 \%$, which is more or less equal to the dry matter content of the DRY diet. In trials in which wet by-products were fed separately and the total amount of ensiled products (roughage and by-products) was not above $50 \%$ of total ration dry matter, no negative influence on feed intake was observed (de Brabander et al., 1980; Schingoethe et al., 1983; Porter et al., 1977; Dulphy et al., 1978; Castle \& Watson, 1982). The high proportion of ensiled products in the diets fed in our trial (80-85\%) may have been important in this respect.

Energy and protein intake of the DRY diet was significantly higher. The combination of the higher total dry matter intake and the higher energy and protein content of the dehydrated by-products caused this difference.

The ratios between energy requirement and intake and protein requirement and intake were significantly different between the groups, both in favour of the dry diet. The higher intake in the first weeks of lactation was mainly responsible for this difference (Figs. 1 and 2). The supply of energy of the total experimental period was approximately $100 \%$ for the DRY diet, whereas the WET group was fed ca. $8 \%$ below requirements. The supply of protein was $114 \%$ for the DRY diet and $105 \%$ for the WET diet. The amount of milk produced was not significantly different between the groups. There was a tendency for a higher milk production with the DRY group, which may simply reflect higher intake. Differences in milk produc-

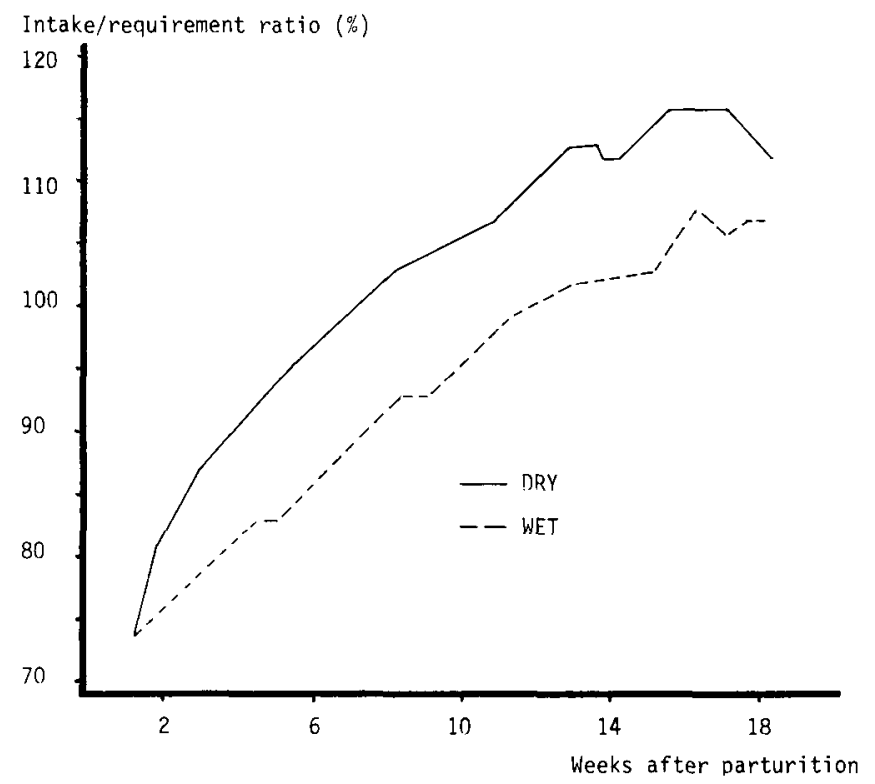

Fig. 1. The Net Energy Lactation intake/requirement ratio of the DRY and WET diet. 


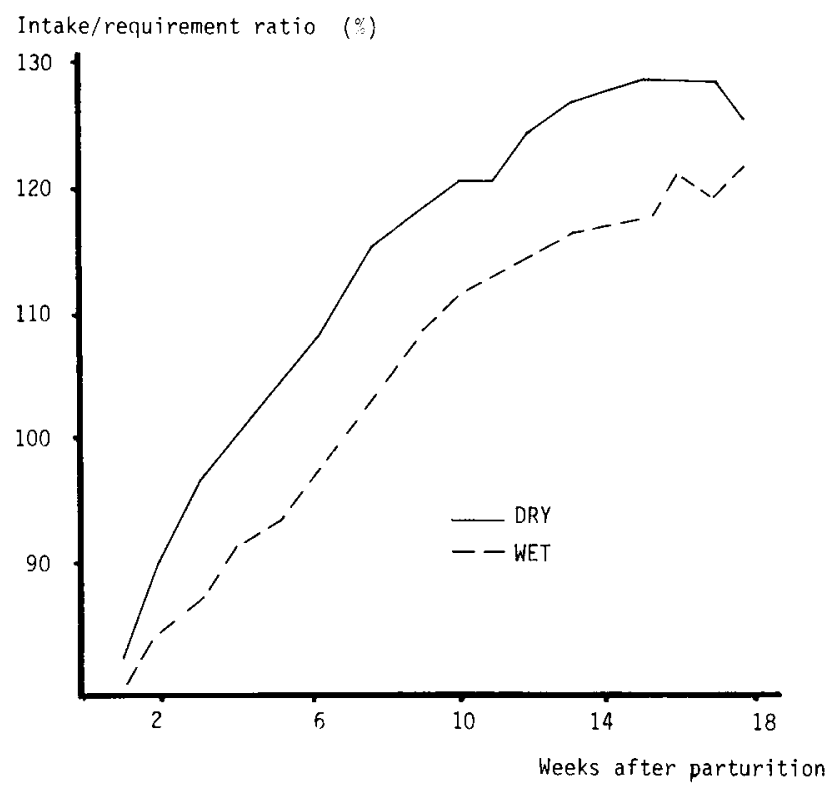

Fig. 2. The digestible crude protein intake/requirement ratio of the DRY and WET diet.

tion were significant in the first eight weeks of lactation. Afterwards the differences decreased. At the same time feed intake of the WET diet was increased, while intake of the DRY group remained constant or decreased slightly.

Milk fat content and total amount of milk fat produced was not significantly different between the groups: for individual by-products the effect on milk fat is different. De Brabander et al. (1980) found lower milk fat percentages when feeding wet beet pulp, in which some $10 \%$ of the moisture had been removed by pressing, leaving a residue with approximately $18 \%$ dry matter. No influence was found, however, when wet brewers' grains and maize gluten feed were fed (Staples et al., 1984; Polan et al., 1985; Murdock et al., 1981).

The protein production and the protein content of the milk were significantly lower for the WET diet (Figs. 3 and 4, Table 6). Staples et al. (1984) found lower protein percentage when feeding wet maize gluten feed, while Schingoethe et al. (1983) found no influence. Murdock et al. (1981) found no influence when feeding wet brewers' grains. De Brabander et al. (1980) found higher milk protein contents when feeding pressed beet pulp. A reduced milk protein content may result from either a negative energy balance or from an inadequate protein supply from the gastrointestinal tract. Due to a negative energy balance either insufficient protein as compared to energy is mobilized from body reserves or protein is being used as a source of energy. An inadequate protein supply may result from excessive degradation of feed protein or from an inadequate microbial protein synthesis in the rumen.

With regard to the influence of a negative energy balance, this situation was 


\section{H. DE VISSER AND S. TAMMINGA}

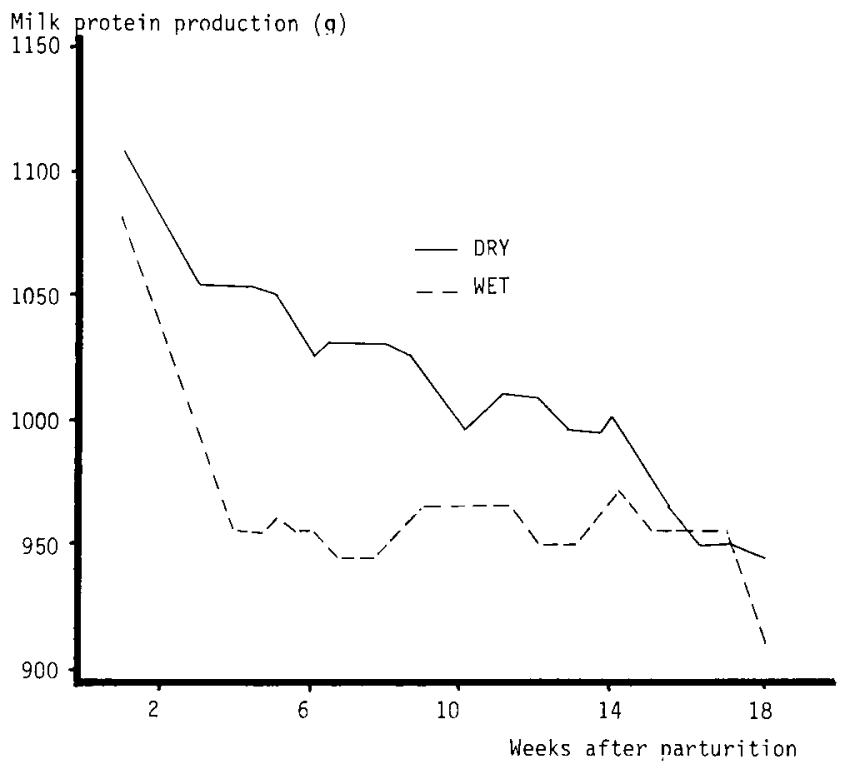

Fig. 3. The milk protein production of the DRY and WET diet.

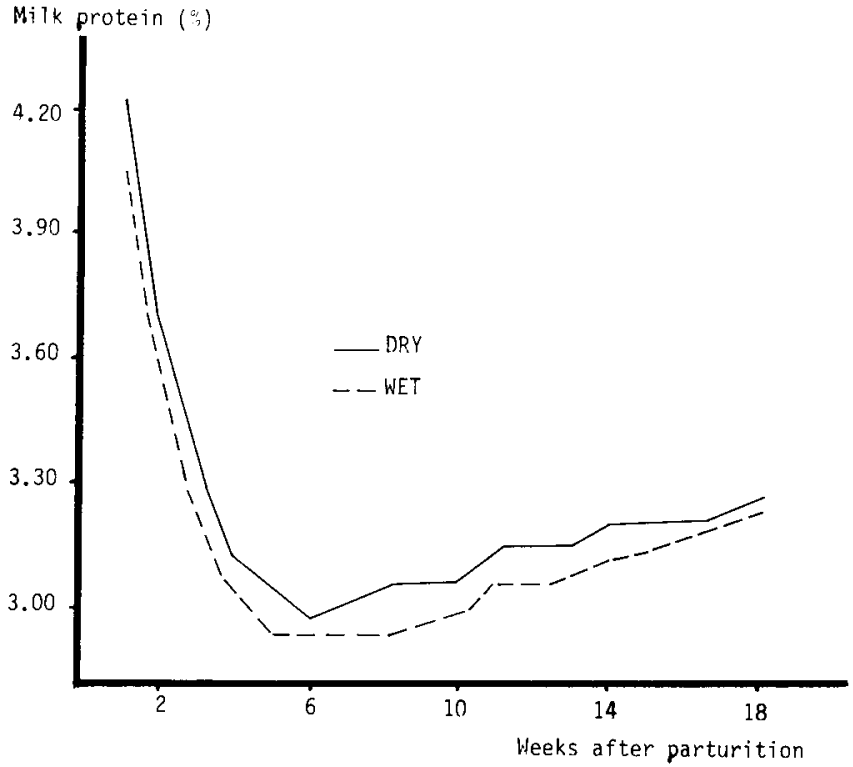

Fig. 4. The milk protein percentage of the DRY and WET diet, 
maintained longer on the WET than on the DRY diets (Fig. 1). From Fig. 4 it can be seen that the milk protein content does not start to rise again after the initial sharp fall post partum until the energy supply equals the animal's demand. This latter situation occurred in the weeks 5 and 10 for the DRY and WET diets, respectively, and this moment coincides rather well with the start of the rise in milk protein content.

However after energy supply had started to exceed demand, the difference in milk protein content between DRY and WET diets remained. Additional research (Robinson et al., 1987b) showed that ruminal non-bacterial non-ammonia-N, as proportion of $\mathrm{N}$ intake, did not differ between DRY and WET diets, suggesting only negligible differences in rumen degradation of feed $\mathrm{N}$ due to the diet. There was however a significant difference in bacterial organic matter $(\mathrm{OM})$ as $\%$ of rumen OM in favour of DRY diets. This difference may have led to a higher supply of microbial $\mathrm{N}$ after feeding the DRY diets, resulting in an increased milk protein content. Feeding large quantities of a dairy ration as ensiled products may have a negative influence on energy availability for rumen microbes, because of the extraction of part of the energy by microbes during the ensiling process. The efficiency of microbial synthesis from those diets was lower than from non-ensiled diets (Miller, 1982; Van Soest, 1982; Anonymous, 1984). Also the results of the rumen fermentation study of Robinson et al. (1987a, b) showed a lower ammonium concentration for the DRY diets, despite a higher $\mathrm{N}$ to net energy ratio in DRY diets. This indicates that more ammonia was captured by bacteria with the DRY diets.

Fat-corrected milk (FCM) production (4\%) tended to be higher for the DRY diet. It could be explained by the higher intake. FCM production showed the same pattern as milk production.

Live weight did not differ between the groups. The higher energy intake for the DRY diet was not reflected in a higher increase in live weight. The DRY group showed two weeks earlier an increase in bodyweight, but this was not significant.

\section{Conclusions}

Digestibility of brewers' grains and the maize gluten feed differed between the dehydrated and ensiled form, probably due to the quality of the material.

No interaction was found between ISOPLUS ${ }^{\mathrm{TM}}$ as an additive and type of diet (WET or DRY).

No significant differences with regard to feed intake and milk production or milk composition were found between cows fed diets with or without the additive. Type of roughage and number of different ingredients in the diet are most likely responsible for the absence of an effect of ISOPLUS ${ }^{\mathrm{TM}}$.

The dry matter, energy and protein intake was negatively influenced by the use of wet by-product ingredients. Also the milk protein content and milk protein production was significantly decreased. Lower digestibility and reduced microbial protein synthesis in the rumen seems the most plausible explanation for this observation. 


\section{Acknowledgements}

The authors like to thank $\mathrm{Mr} \mathrm{L}$. de Jong and $\mathrm{Mr} \mathrm{W}$. Bakker for taking care of the animals. We also thank $\mathrm{Mr} \mathrm{A}$. Steg for measuring the digestibility of the ingredients of the rations. This research was funded partly by Eastman Chemicals Division, Eastman Kodak Company, Kingsport, USA.

\section{References}

Alvey, N., N. Galwey \& P. Lane, 1982. An introduction to Genstat. Academic Press, London, 152 pp. Anonymous, 1984. Nutrient requirement of ruminants. Livestock Supplement No 1, Commonwealth Agricultural Bureaux.

Castle, M. E. \& J. N. Watson, 1982. A mixture of malt distillers' (draff) and Pot ale syrup as a food for dairy cows. Animal Production 35: 263-267.

Brabander, D. L., J. V. Aerts, Ch. V. Boucqué \& F. X. Buysse, 1980. Invloed van ingekuilde voorgeperste pulp op de ruwvoederopname, de melkproduktie en de melksamenstelling bij melkvee. Landbouwtijdschrift 33: 933-943.

Dulphy, J. P., J. Bony \& J. P. Andrieu, 1978. Utilisation des pulpes de betteraves surpressées par les vaches laitières. Bulletin Technique CRVZ de Theix 34: 15-21.

Es, A. J. H. van, 1978. Feed evaluation for ruminants. 1. The systems in use from May 1977 onwards in the Netherlands. Livestock Production Science 5: 331-335.

Lahr, D. A., D. E. Otterby, D. G. Johnson, J. G. Linn \& R. G. Lundquist, 1983. Effects of moisture content of complete diets on feed intake and milk production by cows. Journal of Dairy Science 66: 1891-1900.

Miller, E. L., 1982. The nitrogen needs of ruminants. Occasional publication of British Society of Animal Production No 6: 79-88.

Murdock, F. R., A. S. Hodgson \& R. E. Riley, 1981. Nutritive value of wet brewers' grains for lactating dairy cows. Journal of Dairy Science 64: 1826-1832.

Papas, A. M., S. R. Ames, R. M. Cook, C. J. Sniffen, C. E. Polan \& L. Chase, 1984. Production responses of dairy cows fed diets supplemented with ammonium salts of Iso C-4 and C-5 acids. Journal of Dairy Science 67: 276-293.

Pierce-Sandner, S. B., A. M. Papas, J. A. Rogers, T. F. Sweeney, K. A. Cummins, H. R. Conrad \& L. D. Muller, 1985. Supplementation of dairy cow diets with ammonium salts of volatile fatty acids. Journal of Dairy Science 68: 2895-2907.

Polan, C. E., T. A. Herrington, W. A. Wark \& L. E. Armentano, 1985. Milk production response to diets supplemented with dried brewers grains, wet brewers grains or soybean meal. Journal of Dairy Science 68: 2016-2026.

Porter, R. M., J. A. Rogers \& H. R. Conrad, 1977. Feed intake, milk production and digestibility in cows fed dried, rewetted and wet brewers' grain. Journal of Dairy Science 60 (Suppl. 1) 142-143.

Robinson, P. H., S. Tamminga \& A. M. van Vuuren, 1987a. Influence of wet vs. dry by-product ingredients and addition of branched chain volatile fatty acids and valerate to dairy diets. 2 . Rumen fermentation and milk production. Netherlands Journal of Agricultural Science (in press).

Robinson, P. H., S. Tamminga \& A. M. van Vuuren, 1987b. Influence of wet vs. dry by-product ingredients and addition of branched chain volatile fatty acids and valerate to dairy diets. 3 . Kinetics of rumen ingesta turnover, whole tract digestibility and some plasma hormone concentrations. Netherlands Journal of Agricultural Science (in press).

Schingoethe, D. J., A. K. Clark \& H. H. Voelker, 1983. Wet corn distillers grains in lactating dairy cow rations. Journal of Dairy Science 66: 345-349.

Soest, P. J. van, 1982. Nutritional ecology of the ruminant. O \& B Books, Corvallis, OR, USA, 374 pp.

Staples, C. R., C. L. Davis, G. C. McCoy \& J. H. Clark, 1984. Feeding value of wet corn gluten feed for lactating dairy cows, Journal of Dairy Science 67: 1214-1220. 
Steg, A., Y. van der Honing \& H. de Visser, 1985. Effect of fibre in compound feeds on the performance of ruminants. In: W. Haresign \& D. J. A. Cole (Eds.), Recent advances in animal nutrition, p. 113129. Butterworths, London.

Tilley, J. M. \& R. E. Terry, 1963. A two stage technique for the in vitro digestion of forage crops. Journal of the British Grassland Society 18: 104-111. 